\title{
COMMENTS
}

\section{A Conflict of Laws Model for Foreign Branch Deposit Cases}

\author{
H. Thomas Byron III $\dagger$
}

Many U.S. banks have tried to take advantage of and contribute to economic growth in developing countries by establishing branches in foreign nations. ${ }^{1}$ When political and economic conditions become unstable, foreign governments have on occasion expropriated the branches' assets. ${ }^{2}$ Depositors unable to withdraw their funds because of the expropriation may attempt to recover from the U.S. bank's home office.

A depositor's ability to recover ultimately depends on the court's choice of law. If U.S. law applies, the depositor usually can recover, because the bank has not repaid its debt to the depositor. Conversely, if foreign law applies, the depositor usually loses because the foreign government's expropriation carries the force of law and extinguishes the debt. Instead of analyzing these foreign branch deposit cases under conflict of laws principles, however, the courts have emphasized two doctrines developed in other contexts.

† A.B. 1987, M.A. 1989, Georgetown University; J.D. Candidate 1991, The University of Chicago.

1 The Board of Governors of the Federal Reserve System defines a "foreign branch" as "an office of an organization ... that is located outside the country under the laws of which the organization is established, at which a banking or financing business is conducted." 12 CFR § 211.2(h) (1990).

${ }^{2}$ A related problem, not explicitly considered here, may arise when a foreign sovereign restricts the flow of foreign currency by imposing exchange controls. See, for example, Wells Fargo Asia Ltd. $v$ Citibank, 852 F2d 657 (2d Cir 1988) (recoverability of Eurodollar time deposits placed in the Manila branch of a U.S. bank affected by Phillipine government exchange controls), vacated and remanded, 110 S Ct 2034 (1990); Peter S. Smedresman and Andreas F. Lowenfeld, Eurodollars, Multinational Banks, and National Laws, 64 NYU L Rev 733 (1989). 
One of these, the ultimate liability doctrine (and its exception the separate entity doctrine), is derived from banking cases litigated during the 1920s. The other, the act of state doctrine, is a quasiconstitutional rule applied in international disputes concerning the actions of a foreign sovereign. These doctrines unnecessarily complicate what would otherwise be a relatively straightforward choice of law analysis. Through territorial debt situs analysis, they require courts to attempt to "localize" the transaction in a mechanical way without explicitly considering its actual contacts with the different jurisdictions involved.

Neither of these doctrines is itself a choice of law principle, but both have choice of law implications. The approaches reflect a background theory of territoriality, which requires application of the law of the jurisdiction in which the dispute's subject matter was located. Strict territoriality, applied under the rubric of debt situs analysis in foreign branch deposit cases, was once the dominant approach to all choice of law problems but has been largely superseded by interest analysis.

To resolve foreign branch deposit cases in a manner that is both clear and consistent with contemporary jurisprudence, courts must first recognize that such cases present a classic conflict of laws problem. Second, courts should resolve this problem as they would any other conflict of laws problem: by explicitly considering and balancing the interests of the affected jurisdictions.

Section I of this Comment presents the territorial doctrines used to resolve recent foreign branch deposit cases. Section II then explains how the parties in such cases may raise those doctrines and describes the analyses employed by courts in recent cases. Section III argues that the real problem in these cases is one of conflict of laws and that courts should treat it as such, and explains how the doctrines currently employed in foreign branch deposit cases operate as territorial choice of law rules.

Section IV critiques the approach courts have taken in recent foreign branch deposit cases by emphasizing the inappropriateness of debt situs analysis and demonstrating that contemporary choice of law jurisprudence prefers interest analysis to strict territorial analysis. Section V proposes that courts faced with foreign branch deposit cases abandon the anachronistic territorial approach in favor of explicit interest analysis.

\section{Territorial Doctrines in Foreign Branch Deposit Cases}

Foreign branch deposit cases frequently turn on the choice between U.S. and foreign banking law. While U.S. state law generally 
enables a depositor to recover on a contract theory, ${ }^{3}$ foreign law, and perhaps U.S. federal law as well, are more likely to favor the bank, as discussed in Section V. Instead of approaching this crucial choice of law inquiry directly, courts have relied on several unrelated territorial doctrines. These doctrines arose in contexts other than conflict of laws. Each relies on the principle of strict territoriality. First, the strict territorial sovereignty principle embodied in the First Restatement of Conflict of Laws attempts to define and respect territorial jurisdictional limits. Second, the ultimate liability and separate entity doctrines of U.S. banking law attempt to apportion responsibilities between banks' home offices and their branches. Finally, the act of state doctrine precludes U.S. courts from examining the validity of certain acts of foreign sovereigns.

A. Territorial Sovereignty and the First Restatement of Conflicts

At the heart of the doctrinal analysis performed in foreign branch deposit cases is the assumption that, if only the territorial nexus of a transaction or event can be discovered, the case can be resolved simply by applying the law of that jurisdiction. Though rarely articulated, this belief harkens back to an earlier day when all conflict of laws questions were approached in terms of localization. ${ }^{4}$

In the mid-nineteenth century, Justice Joseph Story wrote the authoritative U.S. treatise on the conflict of laws. ${ }^{5}$ Story founded his conception of the conflict of laws on a notion of strict territorial sovereignty:

It is plain, that the laws of one country can have no intrinsic force ... except within the territorial limits and jurisdiction of that country. They can bind only its own subjects, and others, who are within its jurisdictional limits; and the latter only while they remain there. No other nation, or its subjects, are bound to yield the slightest obedience to those laws. ${ }^{6}$

Story's view formed the basis for the First Restatement of Conflicts, edited by Joseph Henry Beale, which attempted to pro-

3 See 5B Michie on Banks and Banking § 350 at 391, 394-95 (Michie, 1983).

- For an overview of the development of conflict of laws doctrine in Europe and the United States, see Hessel E. Yntema, The Historic Bases of Private International Law, 2 Am J Comp L 297 (1953), reprinted in Association of American Law Schools, Selected Readings on Confict of Laws 30 (West, 1956) ("AALS Readings").

s Joseph Story, Commentaries on the Conflict of Laws (Hilliard, Gray, 1834) ("Commentaries").

- Id, $\$ 7$ at 7. 
vide specific guidance to courts faced with conflict of laws cases by relying on the notion of exclusive territorial sovereignty. ${ }^{7}$ Such an approach forces courts to "localize" events with multistate contacts-a daunting task. To this end, the Restatement divided the law into categories such as status, corporations, property, contracts, and wrongs, ${ }^{8}$ and further broke down each category into topics. The Restatement established rigid rules for each topic that decreed "where" a particular event would be deemed to have taken place. Because these localization rules served merely to select a jurisdiction whose law would then be construed, theoretically without prior reference to the content of that law, they came to be known (somewhat pejoratively) as "jurisdiction-selecting" rules. ${ }^{\circ}$

Over time, however, courts and commentators realized that the Restatement's jurisdiction-selecting rules made no attempt to determine which jurisdiction's laws should govern the dispute. ${ }^{10}$ As a result, when the rules dictated irrational results, courts invoked one of a variety of escape devices, allowing them to apply their state's law to the cases that were particularly important to it. ${ }^{11}$ Such widespread use of escape devices defeated the Restatement's purpose within a few years of its publication. Although later jurisprudence, including the Second Restatement of Conflicts, has partly moved away from jurisdiction-selecting rules, ${ }^{12}$ the strict territoriality principle continues to be reflected in the doctrines applied in foreign branch deposit cases.

\section{B. The Ultimate Liability and Separate Entity Doctrines}

The ultimate liability doctrine ${ }^{13}$ holds banks responsible as unitary enterprises for the debts incurred by their branches or sep-

: See, for example, Restatement of Conflict of Laws § 98 (1934).

${ }^{3}$ See id, Table of Contents at xxii-xxxiii.

- The phrase comes from David F. Cavers, A Critique of the Choice-of-Law Problem, 47 Harv L Rev 173 (1933).

10 Id at $178,180-81$.

11 For examples of many of the escape devices (including the traditional catch-all, "public policy"), see cases cited in Roger C. Cramton, David P. Currie, and Herma Hill Kay, Conflict of Laws: Cases-Comments-Questions 58-135 (West, 4th ed 1987). The idea that these escape devices implicitly furthered the interests of the forum is explicated in Brainerd Currie, Selected Essays on the Conflict of Laws (Duke, 1963).

12 Restatement (Second) of Conflict of Laws § 6(2) (1971).

1s Although courts have long held a bank's home office ultimately liable for the debts of its offices, this rule has never been referred to by any particular name. For ease of reference, this Comment adopts the language of Trinh v Citibank, 850 F2d 1164, 1168 (6th Cir 1984) (discussed in Section II.B.1.), and refers to this concept as the ultimate liability doctrine. 
arately incorporated subsidiaries. ${ }^{14}$ This doctrine recognizes that banks conduct business at many locations, but attributes all debts to the firm as a single enterprise. ${ }^{16}$ The rationale is that branches "are subject to the supervision and control of the parent bank, and are instrumentalities whereby the parent bank carries on its business, . . . and their business conduct and policies are controlled by the parent bank, and their property and assets belong to the parent bank ...."16 The choice of law effect of the doctrine is to make the law of the bank's principal place of business the law that governs the recoverability of any debt owed by the bank.

In the 1920s, the New York courts carved out an exception to ultimate liability known as the separate entity doctrine. ${ }^{17}$ That doctrine treats each branch and the bank's main office as separate and distinct business entities for the purpose of some arm's-length commercial transactions. ${ }^{18}$ An important implication of the doctrine is that deposits maintained at one branch are payable only at that branch and may not normally be demanded by the depositor or her creditors at the bank's main office or at any other branch. ${ }^{19}$ The separate entity analysis dictates that a debt's situs (territorial location) is in the jurisdiction where the branch is located..$^{20}$

The separate entity doctrine developed in response to the difficulty of interbranch communication before the days of instant telecommunication and global computer networks. If a depositor banked at one particular branch, the records of her accounts (including the authorized signature card and the record of daily balances) were not readily accessible to tellers at other branches. Allowing depositors to demand payment at any branch would have imposed onerous burdens on banks to maintain records of every

14 The main case involving foreign branches is Sokoloff $v$ National City Bank of New York, 130 Misc 66, 224 NYS 102, 114 (S Ct 1927), aff'd mem, 223 AD 754, 227 NYS 907, aff'd, 250 NY 69, 164 NE 745 (1928). The principle had earlier been established in the context of domestic branches. See Bank of United States $v$ Goddard, 2 F Cas 694, 696 (CC D Mass 1829); Worth $v$ Bank of New Hanover, 122 NC 397, 403, 29 SE 775, 776 (1898). See also Patrick Heininger, Liability of U.S. Banks for Deposits Placed in Their Foreign Branches, 11 L \& Pol Intl Bus 903, 924-30 (1979).

$1 s$ See Heininger, $11 \mathrm{~L} \&$ Pol Intl Bus at 924-30 (cited in note 14).

16 Sokoloff, $130 \mathrm{Misc}$ at 73. See also 10.Am Jur 2d Banks $\S \S 326,327$. Heininger describes this concept as "a general principle of corporate responsibility." Heininger, 11 L \& Pol Intl Bus at 924 (cited in note 14).

${ }_{17}$ The separate entity doctrine was first enunciated in Chrzanowska v Corn Exchange Bank, 173 AD 285, 291, 159 NYS 385 (1916).

18 Id at 291; Bluebird Undergarment Corp. $v$ Gomez, 139 Misc 742, 744 (City Ct NY 1931) ("the branch is not a mere 'teller's window'; it is a separate business entity").

10 Bluebird Undergarment, 139 Misc at 744.

${ }^{20}$ See id at $743-45$. 
account at each branch, and to require each branch to check with every other before paying out funds from an account. Moreover, if a depositor could demand payment on the same funds from two branches, and was able to make the second demand before a record of the first had reached the second branch, the bank could face double liability. ${ }^{21}$

Like the ultimate liability doctrine, the separate entity doctrine spawned its own exceptions. ${ }^{22}$ The most important of these for foreign branch deposit cases holds that the separate entity rule does not apply when the branch has been closed or has wrongfully refused payment. ${ }^{23}$ In those circumstances, the situs of the debt is deemed to have "sprung back" to the bank's head office, thus reinvoking the ultimate liability rule. ${ }^{24}$

\section{The Act of State Doctrine}

Another principle applied by the courts in foreign branch deposit cases is the act of state doctrine, which prohibits a U.S. court from reviewing certain acts of a foreign sovereign..$^{25}$ In a typical act of state case, the plaintiff challenges the title to property, alleging that the means by which the foreign government obtained the property (expropriation) was invalid and thus undeserving of rec-

${ }^{21}$ See Cronan $v$ Schilling, 100 NYS2d 474, 476 (S Ct NY County 1950); Newtown Jackson Co. v Animashaun, 148 NYS2d 66, 68 (S Ct Nassau County 1955).

${ }^{22}$ See, for example, Shinto Shipping Co. v Fibrex \& Shipping Co., 425 F Supp 1088, 1091 (N D Cal 1976) (with regard to subpoenas seeking information about accounts in branch banks, "if due to the interplay of the laws of interested states manifest injustice or inordinate hardship might attend this rule's application to an interstate banking system, an exception should be recognized"), aff'd, 572 F2d 1328 (9th Cir 1978).

${ }_{23}$ Sokoloff, 130 Misc at 73.

24 Vishipco Line v Chase Manhattan Bank, N.A., 660 F2d 854, 862 (2d Cir 1981), quoting Heininger, $11 \mathrm{~L} \&$ Pol Intl Bus at 975 (cited in note 14).

${ }^{26}$ The modern version of the doctrine was articulated by Justice Harlan in Banco $\mathrm{Na}$ cional de Cuba $v$ Sabbatino, 376 US 398, 401 (1964): "The act of state doctrine in its traditional formulation precludes the courts of this country from inquiring into the validity of the public acts a recognized foreign sovereign power committed within its own territory." The "classic American statement of the act of state doctrine," id at 416, was announced by the Court in Underhill v Hernandez, 168 US 250, 252 (1897):

Every sovereign State is bound to respect the independence of every other sovereign State, and the courts of one country will not sit in judgment on the acts of another done within its own territory. Redress of grievances by reason of such acts must be obtained through the means open to be availed of by sovereign powers as between themselves.

Nonetheless, the doctrine does not operate to deprive a court of jurisdiction over a dispute. It merely requires a U.S. court to accept the act of a foreign sovereign as a "rule of decision." W.S. Kirkpatrick \& Co. v Environmental Tectonics Corp., 110 S Ct 701, 704 (1990), quoting Ricaud v American Metal Co., 246 US 304, 310 (1918). 
ognition and enforcement by U.S. courts. ${ }^{26} \mathrm{~A}$ foreign action might be denied legal effect in this country if, for example, it violated the U.S. public policy against expropriation without compensation, as courts have often held with regard to confiscatory decrees not covered by the act of state doctrine. ${ }^{27}$

Before applying the act of state doctrine, a court must find that the foreign government's act was public, ${ }^{28}$ committed by a recognized foreign sovereign, ${ }^{29}$ and committed within the territory of the foreign sovereign..$^{30}$ Only when these three requirements are met will U.S. courts refrain from passing on the validity of the act in question..$^{31}$ The most important of these requirements in the foreign branch deposit context is the third: the act of the foreign state must have been committed within its own territory. This is usually referred to as the "situs requirement" because the court must find that the objects of expropriation were within the foreign state at the time the act was committed. In Banco Nacional de Cubav

28 See, for example, Sabbatino, 376 US 398; Ricaud, 246 US 304; Oetjen $v$ Central Leather Co., 246 US 297 (1918). But note that the first instance of the act of state doctrine in U.S. law involved allegations of tortious injury by a foreign government official. Underhill, 168 US 250.

${ }^{27}$ See, for example, Republic of Iraq v First National City Bank, 353 F2d 47, 51 (2d Cir 1965).

${ }^{23}$ See, for example, Sabbatino, 376 US 398, and cases cited therein at 416-18; Ricaud, 246 US 304; Oetjen, 246 US 297.

20 Although Sabbatino explicitly stated that the foreign government must be "extant and recognized by this country at the time of suit," 376 US at 428 , later courts have largely ignored this requirement. The idea that only acts of recognized governments were subject to the doctrine was suggested in earlier cases involving expropriations by the Soviet government prior to U.S. recognition. See, for example, Sokoloff, 250 NY at 81. Sabbatino's emphasis of the existence and recognition requirement was prompted by the need to explain an earlier controversial case involving the expropriation of Jewish citizens' property by the German government before and during World War II. See Bernstein v N.V. NederlandscheAmerikaansche Stoomvaart-Maatschappij, 210 F2d 375 (2d Cir 1964), in which the Second Circuit found the doctrine inapplicable following receipt of a letter from the State Department urging such a result. The Bernstein exception remained controversial even following Sabbatino's attempt to explain it away on different grounds. See First National City Bank $v$ Banco Nacional de Cuba, 406 US 759 (1972).

so The problem of the situs of the property subject to the foreign government's act is crucial to the resolution of foreign branch deposit cases and is treated at length below. See Section IV.A.

s1 In the modern era, the Supreme Court has rarely reached a consensus (or even a majority) on the doctrine's purpose or the limits of its application. In First National City Bank v Banco Nacional de Cuba, 406 US 759 (1972), the three-member plurality decided the case on a ground that the concurrence and the dissent (amounting to six justices) rejected outright. The three opinions are irreconcilable. See Banco Nacional de Cuba v Chase Manhattan Bank, 658 F2d 875, 884 (2d Cir 1981). Similarly, Alfred Dunhill of London, Inc. $v$ Republic of Cuba, 425 US 682 (1976), also failed to produce a majority opinion. But see Kirkpatrick, 110 S Ct 701. 
Sabbatino, ${ }^{32}$ and most early act of state cases, ${ }^{33}$ this situs analysis was simple because the expropriated property was usually either real or movable. The U.S. court simply asked where the property was physically located at the time the foreign state acted. If the property was within the country's borders, the act of state was complete. Otherwise, the court could decline to give extraterritorial effect to the expropriation, usually on public policy grounds..$^{34}$ Where the property is not tangible, however, the act is far more difficult to localize.

The act of state doctrine has traditionally rested on avoiding the embarrassment to the executive branch that could result if courts applied the public policy exception to official acts of foreign states. ${ }^{35}$ The embarrassment concern is twofold. First, international comity may require the United States to acknowledge official acts of coequal sovereigns. ${ }^{36}$ Second, the constitutional system of separation of powers commits the conduct of foreign relations to the executive branch, and courts should not interfere with this constitutional mandate by deciding cases that could embarrass the executive. ${ }^{37}$ The act of state doctrine thus resembles both choice of law principles $^{38}$ and the political question doctrine, ${ }^{39}$ although these concerns are not necessarily exclusive or inconsistent. ${ }^{40}$ The

s2 376 US 398 (1964).

${ }^{33}$ See, for example, Ricaud, 246 US 304; Oetjen, 246 US 297.

s4 "Public policy" was a traditional escape device invoked under the First Restatement of Conflicts and earlier jurisdiction-selecting choice of law rules. See, for example, Loucks $v$ Standard Oil Co. of New York, 224 NY 99, 110, 120 NE 198, 201 (1918); see also Restatement (Second) of Conflict of Laws $\S 90$. The act of state doctrine, however, trumps the public policy exception and mandates that the U.S. court give effect to the action in spite of (in fact, because of-as there would otherwise be no need for the rule) the fact that it would contravene the American forum's public policy against expropriation without compensation. See Republic of Iraq $v$ First National City Bank, 353 F2d 47, 51 (2d Cir 1965); Restatement (Third) of the Foreign Relations Law of the United States $\$ 443$, Reporters' Note 1 (1987); Louis Henkin, Act of State Today: Recollections in Tranquility, 6 Colum J Transnatl L 175, 178 (1967).

${ }^{35}$ See Restatement (Third) of the Foreign Relations Law of the United States $\S 443$, comment a.

${ }^{38}$ This justification for the doctrine proceeds from the reasoning of Underhill. See Diane P. Wood, Government Involvement and International Antitrust Enforcement, Proceedings of Fordham Corporate Law Institute 17, 24 (Matthew Bender, 1988) ("Government Involvement"). Note, however, that Sabbatino claimed the doctrine was not required either by international law or by comity. 376 US at $421-22$.

${ }^{37}$ See Sabbatino, 376 US at 423-24, 431-32.

${ }^{38}$ See Dunhill, 425 US at 725-27 (Marshall dissenting).

39 See First National City Bank, 406 US at 787-88 (Brennan dissenting).

to See Wood, Government Involvement at 25 (cited in note 36) ("Nothing in Sabbatino rejects comity as an equally important factor for a properly restricted act of state doctrine."). 
effect, however, of refusing to examine the validity of an act of state is systematically to choose the foreign state's law. ${ }^{41}$

\section{Foreign Branch Deposit Cases}

\section{A. A Typical Case}

When a foreign government expropriates a U.S. bank's foreign branch assets, the branch's depositors are unable to withdraw those funds directly from the branch. In most cases, the expropriation is the act of a revolutionary government not particularly sympathetic to the concerns of depositors, so there is little recourse available from the country's central bank or other governmental entities charged with carrying on the business of the expropriated foreign branches.

To recover the expropriated funds, depositors often sue in U.S. federal court or in a court of the state where the bank is . chartered or has its principal place of business. To prevail, the depositor must convince the court that the parent bank itself is responsible for the debts incurred by its foreign branch. Consequently, the depositor relies explicitly on the ultimate liability doctrine.

The bank may offer a number of defenses. First, casting the case as a choice of law problem, the bank may assert that foreign, not U.S., law applies to the dispute, and that foreign law prevents recovery, an assumption usually supported by the fact of the expropriation itself. Indeed, revolutionary decrees announcing expropriation policies often explicitly carry the force of law and would be enforced by the new government's judicial system in spite of their possible inconsistency with the laws or policies of the former regime. U.S. courts are prohibited from finding that the expropriation violated the foreign state's own law. ${ }^{42}$ This defense invokes the jurisdiction-selecting strict territorial model of the First Restatement.

A second defense the U.S. bank may offer is that the parent bank should not be held liable for the debts at issue. This defense implicitly assumes that U.S. law applies to the dispute, and looks to the intricate structure of the ultimate liability and separate en-

41 Restatement (Third) of the Foreign Relations Law of the United States $\S 443$, Reporters' Note 1.

42 This is the lesson of the early act of state cases. See Banco de Espana v Federal Reserve Bank of New York, 114 F2d 438, 443 (2d Cir 1940) (citing Underhill, Oetjen, and Ricaud). 
tity doctrines. The bank will claim that the branch should be considered a separate entity whose debts should not be imputed to the parent.

Finally, the bank may assert that the case turns on the validity of a public act of a foreign sovereign and so must be governed by the act of state doctrine. If applicable, this doctrine prevents U.S. courts from reviewing the expropriation, effectively absolving the bank from liability. This defense may work in conjunction with the first one. Choice of foreign law might be defeated by invoking public policy against expropriation, but the act of state doctrine prevents inquiry into the foreign sovereign's act. ${ }^{43}$

None of these defenses is immediately dispositive of the claim. With regard to choice of law, the depositor can argue that U.S. law should apply, whether because of significant contacts with this country or because the parties reasonably expected, or even agreed, that it would. ${ }^{44}$ In response to the separate entity defense, the depositor may invoke the "spring back" exception, which requires payment by the parent when the branch has closed or otherwise wrongfully refused payment. Countering the act of state doctrine, the depositor may claim that the court need not review the validity of the foreign act in order to find the bank liable. ${ }^{45}$

The depositor's strongest responses, like the bank's strongest defenses, all rely on the debt's situs. If the depositor can prove that the situs of the debt was in the United States, the court will probably apply U.S. law, find the bank ultimately liable, and hold the act of state doctrine inapplicable. Of course, a finding that the debt's situs was in the foreign state is not dispositive, but it would resolve the most powerful objections to the bank's defenses. Thus, virtually the entire case, including intricacies of three separate areas of law, turns on the speculative task of locating the "situs" of the debt.

\section{B. Recent Foreign Branch Deposit Cases}

Five recent cases have involved depositors' attempts to recover foreign branch deposits after expropriation by a foreign 'government. Two of these involved claims by Vietnamese nationals against U.S. banks that closed their Saigon branches shortly before the fall of the South Vietnamese government. The courts relied

\footnotetext{
4s See note 34.

14 See Restatement (Second) of Conflict of Laws vii-viii.

${ }^{45}$ See Kirkpatrick, $110 \mathrm{~S} \mathrm{Ct}$ at 704.
} 
primarily on the interaction of the ultimate liability and separate entity doctrines. The other three cases involved claims against a U.S. bank that closed its Havana branch when Fidel Castro nationalized the banks. The Cuban cases were decided primarily on the act of state doctrine's situs requirement. Taken as a whole, these five cases reflect dissatisfaction with the territoriality principle, yet only one court attempted to use a method other than the ultimate liability, separate entity, and act of state doctrines.

\section{The Vietnamese cases.}

Vishipco Line $v$ Chase Manhattan Bank ${ }^{46}$ and Trinh $v$ Citibank ${ }^{47}$ involved claims against large U.S. banks based on the banks' closure of their Saigon branches just days before the South Vietnamese government fell in $1975 .{ }^{48}$ In both cases, the plaintiffs were South Vietnamese nationals when they made the deposits and U.S. residents by the time they brought suit. ${ }^{49}$ In both cases, the courts held the banks liable under the ultimate liability doctrine. In Vishipco, the court explicitly applied New York law to the dispute. ${ }^{50}$ In Trinh, although the court claimed to apply Vietnamese law, it in fact relied on the American ultimate liability principle, and referred extensively to Vishipco's analysis. ${ }^{51}$

To avoid the effect of the separate entity doctrine, both courts emphasized that the defendants had closed their Saigon branches before the South Vietnamese government fell and the new government nationalized the banks. ${ }^{52}$ The Vishipco court found that the situs of the debt sprang back to Chase's home office in New York once the Saigon branch ceased operations. ${ }^{53}$ Likewise, the Trinh

4660 F2d 854 (2d Cir 1981).

47850 F2d 1164 (6th Cir 1988).

4 Two other cases alleging similar facts, filed after Trinh and Vishipco, were dismissed by the federal district court as barred by New York's statute of limitations. Tat Bav Chase Manhattan Bank, 616 F Supp 10 (S D NY 1984), aff'd without opinion, 762 F2d 991 (2d Cir 1985); Ngoc Dung Thi Tran v Citibank, 586 F Supp 203 (S D NY 1983).

40 850 F2d at 1166; 660 F2d at 856-57. Trinh v Citibank, 623 F Supp 1526, 1529 (E D Mich 1985).

so 660 F2d at 860.

${ }^{61}$ The Trinh court's situs determination allowed it to claim to apply the law of South Vietnam (prior to the institution of the revolutionary government) and to ignore the effect under Vietnamese law of the expropriation decree. 850 F2d at 1167-71. The court interpreted the law of South Vietnam, based on what seems to be scanty and equivocal evidence, as consistent with its analysis of the American ultimate liability doctrine. Id at 1169.

B2 $850 \mathrm{~F} 2 \mathrm{~d}$ at $1166 ; 660 \mathrm{~F} 2 \mathrm{~d}$ at 862.

ss $660 \mathrm{~F} 2 \mathrm{~d}$ at 862, quoting Heininger, $11 \mathrm{~L} \& \mathrm{Pol}$ Intl Bus at 975 (cited in note 14). 
court emphasized that "one of the 'special circumstances' triggering liability against the home office is the closing of a branch."

The two courts also avoided the act of state doctrine through their situs analysis. Vishipco followed the often-repeated rule that a debt's situs is in a foreign country only if "that state has the power to enforce or collect it." Trinh applied the same rule and specifically interpreted the new Vietnamese government's decree nationalizing banks as applying only to the bank's assets, not to its liabilities. Because Citibank had closed its Saigon branch before the decree was issued, the decree had no effect on the branch's debts to depositors. The liability for those debts had already sprung back to Citibank's home office. ${ }^{56}$ Consequently, the act of state doctrine could not apply. Both cases used the same basic approach to decide the dispute.

\section{The Cuban cases.}

Garcia $v$ Chase Manhattan Bank, ${ }^{57}$ Perez $v$ Chase ManhattanBank, ${ }^{58}$ and Edelmann $v$ Chase Manhattan Bank $k^{59}$ involved attempts to recover on certificates of deposit (CDs) purchased from Chase's Cuban branches before Fidel Castro's rise to power in 1959 , and his government's nationalization of banks in 1960. On identical facts, and apparently proceeding under the same situs inquiry, the Garcia and Perez courts reached opposite conclusions. Both courts relied on the formulation that a debt is governed by the law of the place where it is to be repaid. In both cases, Cuban nationals bought Chase CDs in Cuba with the understanding that they could be redeemed, in dollars, at any Chase branch worldwide. ${ }^{60}$ In Garcia, these facts led the Second Circuit to rule that the depositor should recover, while in Perez, the New York Court of Appeals held that the bank should prevail.

- The court in Garcia considered the effect of the Cuban government's nationalization decree and found that it did not relieve

\footnotetext{
os $850 \mathrm{~F} 2 \mathrm{~d}$ at $1168-69$ (emphasis in original).

s3 660 F2d at 862, quoting Menendez v Saks \& Co., 485 F2d 1355, 1364 (2d Cir 1973), rev'd on other grounds as Alfred Dunhill of London $v$ Republic of Cuba, 425 US 682 (1976). The court also noted that this requirement follows from the rule in Harris $v$ Balk, 198 US 215 (1905) (power to enforce payment of a debt depends on jurisdiction over the debtor), overruled (with respect to personal jurisdiction) by Shaffer $v$ Heitner, 433 US 186 (1977).

se Trinh, 850 F2d at 1171-72.

s7 735 F2d 645 (2d Cir 1984).

s8 61 NY2d 460, 463 NE2d 5 (1984).

Bo 861 F2d 1291 (1st Cir 1988).

${ }^{\circ}$ Garcia, 735 F2d at 646-47; Perez, 463 NE2d at 6.
} 
Chase from liability on the debt owed its depositors. ${ }^{61}$ The court did not explicitly consider the ultimate liability or the separate entity doctrines, but it did quote Vishipco's statement that Chase " 'accepted the risk that it would be liable elsewhere for obligations incurred by its branch." "B2 The Garcia court found that the act of state doctrine did not apply because the situs of the debt was not wholly within Cuba at the time of the decree. ${ }^{63}$ Because the CD was redeemable anywhere in the world, the court found that the situs requirement had not been completely met; U.S. courts were thus not precluded from reviewing the validity of the Cuban decree.

On the same facts, the Perez court held that "[o]nly when a debt or other obligation is not payable at all in the confiscating State would the Act of State doctrine be inapplicable." ${ }^{64}$ Because the debt could have been redeemed in Cuba, the court found that the act of state doctrine prevented any inquiry into the effect of the expropriation decree. For the Perez court, the debt situs analysis under the act of state doctrine was dispositive; it did not address the role of the ultimate liability and separate entity doctrines.

In Edelmann, the First Circuit held in favor of the depositor. Instead of focusing on the ultimate liability, separate entity, or act of state doctrine, however, the court proceeded with a straightforward choice of law analysis according to principles set forth in the Second Restatement of Conflict of Laws. ${ }^{65}$ By analyzing a number of factors in its choice of law decision, the court concluded that New York law should apply and that the depositor was thus entitled to recover from Chase's home office.

\section{The Conflict of Laws Problem}

The fundamental question in foreign branch deposit cases is whether U.S. or foreign law should govern the dispute. The ultimate liability, separate entity, and act of state doctrines all attempt to resolve this question by "localizing" the transaction in either the place where the parent bank has its home office or the place where the branch is located. These doctrines all implicate

735 F2d at 649.

62 Id at 650 , quoting Vishipco, 660 F2d at 863 .

cs Id at 650-51.

$463 \mathrm{NE2d}$ at 9 (emphasis added).

ss 861 F2d at 1295, citing Restatement (Second) of Conflict of Laws \& 6(2). For the court's cursory rejection of the act of state doctrine, see 861 F2d at 1302-04. 
analysis of the debt's situs. They ultimately operate in these cases as conflict of laws rules, even though they were developed in other contexts for other purposes.

Although the ultimate liability and separate entity doctrines were not originally developed as conflict of laws rules, they have the effect of mandating a certain choice of law outcome when applied in foreign branch deposit cases. The ultimate liability doctrine exhibits the characteristics of a territorial localizing rule by resolving which of multiple jurisdictions will regulate the outcome of a dispute. The doctrine does so based on largely arbitrary contacts between the parties and the competing jurisdictions, and does not permit different outcomes based on varied fact patterns. Similarly, the separate entity doctrine operates as a jurisdiction-selecting choice of law rule by localizing a bank's obligations at the location of the branch.

The claim that the act of state doctrine also operates primarily as a conflict of laws rule has the support of both judges and scholars. Professor Louis Henkin originated this view in the academic literature: the "[a]ct of state [doctrine] is a special rule modifying the ordinary rules of conflict of laws. ... [It] says that the foreign 'law' (i.e., the act of state) must govern certain transactions and that no public policy of the forum may stand in the way." Dunhill, Justice Marshall's dissent asserted that, unlike the doctrine of sovereign immunity, the act of state doctrine "merely tells a court what law to apply to a case."

6s Henkin, 6 Colum J Transnatl L at 178 (cited in note 34). See Louis Henkin, The Foreign Affairs Power of the Federal Courts: Sabbatino, 64 Colum L Rev 805, 820-21 (1964); Frederic L. Kirgis, Jr., Understanding the Act of State Doctrine's Effect, 82 Am J Intl L 58 (1988). See also The International Rule of Law Act, Hearings on S 1434 before the Subcommittee on Criminal Law of the Senate Committee on the Judiciary, 97th Cong, 1st Sess, 22-29 (1981) (statement of Don Wallace, Jr.). Wallace claims that the origin of the doctrine lies with "the full faith and credit clause idea, from the interstate context." This suggests that, just as the U.S. Constitution requires states to respect each other's laws, the act of state doctrine requires the nation as a whole to respect the laws of foreign states.

67425 US at 726. Justice Marshall's dissent also commanded the votes of Justices Brennan and Stewart, the only members of the Sabbatino majority remaining on the Court in 1976. Marshall continued by quoting Sabbatino: "[the doctrine] "concerns the limits for determining the validity of an otherwise applicable rule of law." "Id, quoting 376 US at 438.

Monroe Leigh, while legal advisor for the State Department (immediately after the Dunhill decision), asserted that "[m]uch of the present uncertainty derives from the Supreme Court's diversion of the act of state defense from its historical origins. Instead of perpetuating the doctrine's conflict of law foundations, the Court has transformed the doctrine into an expression of judicial sensitivity to the conduct of foreign relations." Monroe Leigh and Michael D. Sandler, Dunhill: Toward a Reconsideration of Sabbatino, $16 \mathrm{Va} J$ Intl L 685, 687 (1976). Interestingly, Justice White's dissent in Sabbatino also asserted that the roots of the act of state doctrine lay in conflict of laws principles, specifically the rule 
Moreover, the territorial choice of law results of applying the act of state doctrine are quite apparent in foreign branch deposit cases, because the doctrine's applicability turns on situs analysis. ${ }^{68}$ "If a foreign government's actions play some part in [a dispute] and no violation of international law is alleged, then the act of state doctrine is essentially a choice of law rule." ${ }^{\text {"99 }}$ When a U.S. court deems the situs of a debt to be within the territory of the foreign state (and the doctrine's other conditions are satisfied), the court must decline to pass on the foreign act's validity, regardless of which jurisdiction's law otherwise would have applied. In effect, though not in form, a U.S. court applying the act of state doctrine to a foreign branch deposit case simply applies the foreign law that restricted the availability of the deposits in the first instance.

A recent Supreme Court case, W.S. Kirkpatrick \& Co. v Environmental Tectonics Corp ${ }^{70}$ implicitly recognized that the act of state doctrine plays an important choice of law role. In that case, a unanimous Court permitted a civil suit for damages arising out of the plaintiff's failure to receive a contract with a foreign government because the defendant had bribed foreign government officials in violation of both U.S. and foreign law. The Court held that the act of state doctrine did not apply because the case did not call into question the validity of a foreign sovereign's act. ${ }^{71}$ According to the Court, the doctrine applied only if a suit would otherwise "require[] a court to declare invalid, and thus ineffective as 'a rule of decision for the courts of this country,'. the official act of a foreign sovereign." 22 The Court noted that "act of state issues only arise when a court must decide-that is, when a case turns upon-the effect of official action by a foreign sovereign." ${ }^{\prime 3} \mathrm{Al}-$ though the Court found it unnecessary to discuss the doctrine's origin or proper role, ${ }^{74}$ it implicitly recognized the doctrine's choice

that the lex loci should govern questions of title to property. 376 US at 454 . See also Industrial Investment Development Corp. v Mitsui \& Co., 594 F2d 48, 51 (5th Cir 1979); Callejo $v$ Bancomer, 764 F2d 1101, 1114 (5th Cir 1985); and cases cited in Michael Gruson, The Act of State Doctrine in Contract Cases as a Conflict-of-Laws Rule, 1988 U III L Rev 519.

* See Restatement (Third) of the Foreign Relations Law of the United States \& 443, Reporters' Notes 1, 4; Gruson, $1988 \mathrm{U}$ Ill L Rev at 520-29 (cited in note 67).

Bo Wood, Government Involvement at 28 (cited in note 36 ) (antitrust context).

70110 S Ct 701 (1990).

71 Id at 707.

72 Id at 704, quoting Ricaud, 246 US at 310 (internal citation omitted).

73 Id at 705 (emphasis in original).

74 The parties briefed and argued the applicability of several controversial exceptions to the doctrine, all going to its purpose. But the Court found it "unnecessary [] to pursue those inquiries, since the factual predicate for application of the act of state doctrine [did] not exist." Id at 704. 
of law effects. The Court emphasized that the doctrine requires U.S. courts to treat the foreign act of state as a "rule of decision," "and that it is not some "vague doctrine of abstention."75

That the act of state doctrine operates as a territorial conflict of laws rule can also be discerned from the fact that courts have treated the doctrine much the same as they treated the First Restatement's territorial rules: by creating escape devices. ${ }^{78}$ Courts have used the doctrine's limited scope, especially the requirements that the foreign government be recognized at the time of the trial and that the act be done within its own borders, to carve out exceptions to it.

\section{The Inappropriateness of Contemporary Doctrines in Foreign Branch Deposit Cases}

The courts' analytical methods in foreign branch deposit cases share the underlying premises of the territorial principle of the First Restatement of Conflicts and are subject to the same criticisms. In fact, the problem in foreign branch deposit cases is even more acute because the rules applied in these cases are inappropriate to the problem. Courts developed the separate entity and act of state doctrines to deal with problems completely distinct from those presented in foreign branch deposit cases. Moreover, the separate entity doctrine rests on factual premises no longer applicable in an age of computerized records and satellite communication. And the act of state doctrine, as applied in these cases, relies on a situs analysis that serves only to obscure the problems raised by disputes over intangible property such as debt.

\section{A. Situs Analysis as an Anachronistic Approach}

Application of the ultimate liability, separate entity, and act of state doctrines to foreign branch deposit cases results in a choice of law analysis that suffers from the same methodological shortcomings as the First Restatement's territorial analysis. Like the Restatement rules, the three doctrines are based on arbitrary contacts, are jurisdiction-selecting (because they do not consider the content of the laws at issue), and have generated numerous escape devices.

\footnotetext{
78 Id at 705, quoting Ricaud, 246 US at 310.

${ }^{76}$ See Michael J. Bazyler, Abolishing the Act of State Doctrine, 134 U Pa L Rev 325, 329 n 18 (1986).
} 
1. Ultimate liability and separate entity doctrines.

The ultimate liability and separate entity doctrines operate as mechanical rules that "localize" the situs of a debt or transaction. Neither doctrine permits inquiry into other factors pertinent to modern choice of law analysis.

The separate entity doctrine has come under strong criticism in recent decades, especially in the federal courts. By 1980, the dearth of recent decisions in which New York state appellate courts had applied the doctrine encouraged a U.S. district court to reject it outright, concluding that "New York courts would today act in a sensible fashion" and discard the doctrine if faced directly with the issue. ${ }^{77}$ The original perceived need for the rule no longer exists, because major banks today use computer networks to link their branches and provide continuously updated account information.

In spite of the dramatic changes in the banking industry, some claim that the separate entity doctrine should still be recognized in international cases. ${ }^{78}$ According to this theory, the doctrine reflects the peculiar needs of the international financial community in the face of the threat of double liability (judgment in both a U.S. and foreign court) for banks with foreign branches. ${ }^{79}$ Although this concern would seem particularly pressing in cases where the action required by the U.S. court could result in violations of local law by the foreign branch, such as production of account information or freezing of assets held in foreign branch accounts, the Supreme Court has held that the separate entity doctrine does not limit the powers of U.S. courts in these cases. ${ }^{80}$

Today, the separate entity doctrine is anachronistic. It developed in response to the states' perceived interest in regulating banks and their relations with depositors. These interests have changed as the nature of banking has changed, requiring a reassessment of the doctrine's contemporary viability. Because the doctrine clearly affects the outcome of a choice of law analysis, it

${ }^{27}$ Digitrex $v$ Johnson, 491 F Supp 66, 69 (S D NY 1980). See also Det Bergenske Dampskibsselskab v Sabre Shipping Co., 341 F2d 50, 53 (2d Cir 1965) (questioning the doctrine's modern relevance).

78 See, for example, Heininger, 11 L \& Pol Intl Bus at 942-43 (cited in note 14).

79 Banks with branches in multiple United States jurisdictions are protected from double liability by the Full Faith and Credit Clause. US Const, Art IV, $\S 1$, cl 1 .

so United States v First National City Bank, 379 US 378, 384-85 (1965) (upholding injunction prohibiting the transfer of assets from a foreign branch account). See also First National City Bank v IRS, 271 F2d 616, 618 (2d Cir 1959) (requiring the production of records of a foreign branch account). 
should be understood in relation to that effect. A court applying it as a choice of law rule in these cases, instead of analyzing all the factors relating to a debt in order to determine the appropriate situs, ${ }^{81}$ must base its situs analysis on a single factor: the location of the branch at which the deposit was made. Such a myopic approach to choice of law problems controverts modern choice of law analysis, which requires the explicit consideration of numerous factors to determine the governing law. ${ }^{82}$ Although the ultimate liability doctrine has not generated the same controversy, it is subject to similar criticisms; it also operates as a jurisdiction-selecting rule and precludes full consideration of the relevant choice of law factors.

\section{Act of state doctrine.}

The act of state doctrine's situs requirement has been critical for courts faced with foreign branch deposit cases. In Vishipco, Trinh, Garcia, and Edelmann, the courts found that the doctrine did not apply because the situs requirement was not met. In Perez, the court decided the case on the act of state doctrine after finding that the situs of the debt was in Cuba at the time of the expropriation; the court did not address the doctrine's other requirements. The problem with either applying or dispensing with the act of state doctrine based solely on the question of situs of the debt is the virtual impossibility of ascertaining in any meaningful and consistent way the situs of intangible property.

While the act of state doctrine itself is probably a necessary element of U.S. foreign relations law, ${ }^{83}$ the application of debt situs analysis is both anachronistic and impractical in defining the act of state doctrine's scope. ${ }^{84}$ Unlike physical property, debt is intangible and its location is consequently more difficult, if not impossible, to discern. In the international banking context, the debt owed

\footnotetext{
$\dot{8}_{1}$ The Fifth Circuit adopted such an "incidents of the debt" analysis in Callejo $v$ Bancomer, $764 \mathrm{~F} 2 \mathrm{~d} 1101$ (5th $\mathrm{Cir}$ 1985). The significance of this break from traditional situs analysis is discussed in Note, The Act of State Doctrine: Resolving Debt Situs Confusion, 86 Colum L Rev 594 (1986).

${ }^{82}$ See Restatement (Second) of Conflict of Laws $\S 6$.

8s Most commentators, though often critical of the courts' treatment of the doctrine, acknowledge its necessity in some form. See, for example, Kirgis, $82 \mathrm{Am} J$ Intl L 58 (cited in note 66); Leigh and Sandler, 16 Va J Intl L 685 (cited in note 67); Wood, Government Involvement (cited in note 36). But see Bazyler, $134 \mathrm{U} \mathrm{Pa} \mathrm{L} \mathrm{Rev} 325$ (cited in note 76).

84 The various tests for determining the situs of debt under the act of state doctrine are compared in Note, 86 Colum L Rev 594 (cited in note 81). The contrary results of Perez and Garcia demonstrate the arbitrariness of these approaches.
} 
by a U.S. bank by virtue of its foreign branch's activities can be said to exist in either the United States or the foreign country, depending on the test adopted..$^{85}$

Even the First Restatement of Conflicts recognized that

[s] uch intangible things as have no position in space cannot be subjected to the jurisdiction of a state because of any territorial power of the state over them. If any state has jurisdiction over an intangible thing, it is by reason of some special circumstances which connect the intangible thing to the state. ${ }^{86}$

In spite of this prescient language, the Restatement (fulfilling its underlying premise of giving effect to the strict territoriality principle) emphasized the state's jurisdiction over the owner of the intangible property. In the case of a debt, "jurisdiction over the debtor will also enable a state to affect the chose in action." 87 This approach, which tracks the rule of Harris $v$ Balk, ${ }^{88}$ has been adopted by many courts, including the Second Circuit, in situs analysis under the act of state doctrine..$^{88}$

The assumption that situs analysis is the only relevant question to be asked in determining whether the act of state doctrine applies suggests that the analysis in fact obscures a simple territorial choice of law determination. If the only question is the location of the property at issue, courts overlook the doctrine's purposes in favor of a formalistic statement of its prerequisites. The difficulty and controversy surrounding debt situs analysis confirm the need for a more appropriate structure within which to analyze foreign branch deposit cases. Many commentators have proposed alternative methods, not dependent on strict territorial principles, to determine when the act of state doctrine applies. ${ }^{90}$

\footnotetext{
so For an analysis of the confusion resulting from competing tests for determining debt situs, see Note, 86 Colum L Rev 594 (cited in note 81); Daniel C.K. Chow, Rethinking the Act of State Doctrine: An Analysis in Terms of Jurisdiction to Prescribe, 62 Wash L Rev 397, 424-30 (1987).

o Restatement of Conflict of Laws § 51, comment a.

${ }^{87}$ Id, comment b.

*8 198 US 215 (1905), overruled (with respect to personal jurisdiction) by Shaffer $v$ Heitner, 433 US 186 (1977).

so Menendez v Saks \& Co., 485 F2d 1355, 1364 (2d Cir 1973), rev'd on other grounds as Alfred Dunhill of London, Inc. $v$ Republic of Cuba, 425 US 682 (1976). The Second Circuit endorsed Harris and Menendez in Vishipco, 660 F2d at 862.

0 See, for example, Gruson, 1988 U Ill L Rev 519 (cited in note 67); Chow, 62 Wash L Rev 397 (cited in note 85); Note, 86 Colum L Rev 594 (cited in note 81); Comment, The Act of State Doctrine and Foreign Sovereign Defaults on United States Bank Loans: A New Focus for a Muddled Doctrine, 133 U Pa L Rev 469 (1985); Note, Foreign Sovereign Immu-
} 
Use of debt situs analysis by courts otherwise willing to adopt contemporary interest analysis for the resolution of conflicts of law poses one of the most serious problems in foreign branch deposit cases. $^{91}$ The strict territorial principle inherent in traditional situs analysis might effectively trump the choice of law analysis. Even if the court finds the act of state doctrine inapplicable, as Edelmann did, it still must confront two fundamentally inconsistent choice of law theories. The result is confusing and inconsistent analyses in foreign branch deposit cases.

Courts faced with foreign branch deposit cases cannot and should not simply ignore the act of state doctrine. This Comment merely argues that, when the act of state involves intangible property such as debt, the traditional situs requirement is an inappropriate means by which to determine the doctrine's applicability. Instead, courts should look to Kirkpatrick's requirement of a challenge to the validity of the foreign state's action in order to invoke the doctrine. In addition, courts should consider whether any of the doctrine's purposes would be furthered by applying it to the case at issue.

\section{B. Abandonment of Strict Territoriality}

Use of the territoriality principle to resolve conflict of laws problems has come under fire since its adoption in the First Restatement of Conflicts in 1934, and has been largely supplanted by broader methods of analysis that balance the interests of those jurisdictions affected by the dispute. The First Restatement's theory-that a universal rule should be followed in each class of cases in order to localize multistate acts-has been criticized on at least three grounds. First, the problem of localizing is often undertaken arbitrarily, without explicit reference to the meaningfulness of the contacts that are given preference. ${ }^{92}$ Second, Beale's rules operated without regard to the content of the laws at issue. Instead, the rules simply "indicate the 'appropriate' jurisdictions whose laws are to determine those controversies that, in one way or another, have failed to respect state lines." ${ }^{\text {93 }}$ Finally, rules based on the nature of the action may classify the action in an arbitrary manner. For example, an action described in contract might be subject to

nity and Commercial Activity: A Conficts Approach, 83 Colum L Rev 1440 (1983).

11 See, for example, Edelmann, 861 F2d at 1294.

92 Walter W. Cook, The Logical and Legal Bases of the Conflict of Laws, 33 Yale L J 457 (1924), reprinted in AALS Readings at 71, 74-82 (cited in note 4).

${ }^{\text {} 3}$ Cavers, 47 Harv L Rev 173 (cited in note 9). 
the law of one state, while the same action, if it could be described in tort, would be subject to the law of another state. ${ }^{94}$

The criticism leveled at jurisdiction-selecting rules applies a fortiori to the ultimate liability, separate entity, and act of state doctrines. While the strict territorial approach might have adequately dealt with tangible property, determining a debt's situs requires a different, and much more difficult, determination. ${ }^{95}$ The debts at issue in branch expropriation cases have contacts with at least two jurisdictions. Accordingly, situs analysis based merely on mechanical attempts to localize the debt may well be impossible. ${ }^{96}$ The jurisdictions of the bank's incorporation and/or principal place of business, the branch's location, and the depositor's domicile all have both a significant interest in the dispute's resolution and a relevant contact with the transaction. Yet courts continue to try to resolve the intractable problem of situs in their attempts to apply (or refrain from applying) the ultimate liability, separate entity, and act of state doctrines. Courts in foreign branch deposit cases have failed to focus on the fact that the necessary inquiry is one of conflict of laws and have instead submerged their choice of law analysis beneath the cover of these doctrines.

\section{An Explicit Interest Analysis Proposal}

Courts need to decide these cases in a way that furthers the interests of the affected jurisdictions, and apportions the risk of expropriation in ways consistent with the laws of those jurisdictions. Contemporary choice-of-law interest analysis provides such a method. ${ }^{97}$ This Section first argues for a federal choice of law sys-

- See, for example, Levy v Daniels' U-Drive Auto Renting, 108 Conn 333, 143 A 163, 164 (1928) (whether an accident in a rented automobile should be characterized as arising under the terms of the rental contract or as tortious operation of an automobile). Most critics of the First Restatement approach have mentioned this difficulty of characterization. See, for example, A. H. Robertson, A Survey of the Characterization Problem in the Confict of Laws, 52 Harv L Rev 747 (1939), reprinted in AALS Readings at 144 (cited in note 4); Walter W. Cook, "Characterization" in the Conflict of Laws, 51 Yale L J 191 (1941), reprinted in Walter W. Cook, The Logical and Legal Bases of the Confict of Laws 211 (Harvard, 1942); Ernest G. Lorenzen, The Qualification, Classification, or Characterization Problem in the Conflict of Laws, 50 Yale L J 743 (1941).

os See Chow, 62 Wash L Rev at 424-25 (cited in note 85); Comment, $133 \mathrm{U} \mathrm{Pa} \mathrm{L} \mathrm{Rev} \mathrm{at}$ 488-89 (cited in note 90).

or Professor Lowenfeld has gone so far as to assert that "the question of the situs of true intangibles may not be capable of an answer at all, and yet intangibles exist and may have value, including value in a law suit." Andreas F. Lowenfeld, In Search of the Intangible: A Comment on Shaffer v. Heitner, 53 NYU L Rev 102, 108 (1978).

${ }^{97}$ In the antitrust context, Professor Wood advocates an approach similar to that suggested here. 
tem, and then discusses the proper method 'of applying interest analysis in foreign branch deposit cases.

\section{A. Source of Choice of Law Authority}

A federal district court sitting in diversity must apply the conflict of laws rules of the state in which it sits..$^{98}$ The application of divergent state rules may involve inconsistent methods and results, however, especially since not all states have adopted a choice of law jurisprudence based on interest analysis. ${ }^{99}$ While such inconsistency may be acceptable within a federal system, the international implications of foreign branch deposit cases heighten the need for uniformity, and thus for a federal choice of law rule.

Although many foreign branch deposit cases have been brought under diversity jurisdiction, these cases also present a federal question. The Edge Act ${ }^{100}$ states that "all suits of a civil nature at common law or in equity to which any corporation organized under the laws of the United States shall be a party, arising out of transactions involving international or foreign banking, ... shall be deemed to arise under the laws of the United States ...."101 This statutory basis for federal question jurisdiction allows courts to avoid the potentially confusing (and internationally embarrassing) problem of following state conflict of law rules, as would otherwise be required under Erie $e^{102}$ and Klaxon. In Aaron Ferer \& Sons, Ltd. v Chase Manhattan Bank, the Second Circuit invoked the Edge Act as a basis for a federal common law of conflict of laws in international banking cases, and used explicit interest analysis to determine the law applicable to the dispute before it. ${ }^{103}$

When the problem is basically one involving choice of law, I would avoid a strict territoriality approach and allow the [act of state] defense when a combination of the foreign state's interests and the contacts with the foreign state point to its greater regulatory claim. . . Finally, in any case where one can assume arguendo that the foreign government's action was legal, and a claim is still stated against the defendants before the court, the act of state defense should be rejected.

Wood, Government Involvement at 31 (cited in note 36 ).

${ }^{83}$ Klaxon Co. $v$ Stentor Electric Mfg., 313 US 487, 496 (1941).

- See Herma Hill Kay, Theory into Practice: Choice of Law in the Courts, 34 Mercer I Rev 521 (1983); Cramton, Currie, and Kay, Confict of Laws at 226-27 nn 2-3 (cited in note 11 ).

10012 USC $\S 611$ et seq (1988).

101 Id at $\S 632$.

${ }^{102}$ Erie RR. Co. v Tompkins, 304 US 64 (1938).

${ }^{103} 731$ F2d 112, 120-21 (2d Cir 1984). 
Applying a uniform federal choice of law scheme to all foreign branch deposit cases would be justifiable even in the absence of the Edge Act. The Supreme Court has explained that it "did not have rules like the act of state doctrine in mind when it decided Erie RR. Co. v Tompkins. . . [R]ules of international law should not be left to divergent and perhaps parochial state interpretations." 104 Even if, as this Comment has suggested, the act of state doctrine does not apply to foreign branch deposit cases, the same rationale applies because these problems also require uniformity in international relations. Indeed, one scholar has recently advanced a comprehensive argument that international choice of law should be understood as an exception to the Erie doctrine, and should be explicitly recognized as an area for federal common law. ${ }^{105}$

\section{B. The Method of Interest Analysis}

A federal choice of law rule, such as that adopted in Aaron Ferer, would allow the courts to replace outdated territorial analysis in foreign branch deposit cases with a more straightforward interest analysis. The interest analysis contemplated by this Comment is consistent with the method first proposed by Brainerd Currie. ${ }^{106}$ Currie's theory emphasized the need to decide international conflict of laws cases in much the same way as wholly domestic cases. A court faced with a case involving multistate contacts must

determine the governmental policy expressed in the law of the forum. It should then inquire whether the relation of the forum to the case is such as to provide a legitimate basis for the assertion of an interest in the application of that policy. This process is essentially the familiar one of construction or inter-

104 Sabbatino, 376 US at 425. For Harlan's purposes, this provides a strong reason to classify the doctrine under the separation of powers rubric. Monroe Leigh, however, has formulated the logical proposition that cases dealing so intimately with foreign relations must of necessity be governed by federal law, and concludes that international cases where the act of state doctrine is routinely applied can and should be governed by some sort of federal common law. Leigh and Sandler, $16 \mathrm{Va} J$ Intl $\mathrm{L}$ at 709-12 (cited in note 67). See also Henkin, 64 Colum L Rev at 806 (cited in note 66). Indeed, a prominent casebook on conflict of laws includes Sabbatino as one of three cases in its subchapter entitled "Federal Common Law." Cramton, Currie, and Kay, Conflict of Laws at 816-38 (cited in note 11).

${ }^{10 s}$ Daniel C.K. Chow, Limiting Erie in a New Age of International Law: Toward a Federal Common Law of International Choice of Law, 74 Iowa L Rev 165 (1988).

${ }_{108}$ Despite widespread criticism of Beale's effort to restate the law of conflicts, no commentator prior to Brainerd Currie formulated a comprehensive theory of conflict of laws to take its place. Larry Kramer, Interest Analysis and the Presumption of Forum Law, $56 \mathrm{U}$ Chi L Rev 1301, 1301-02 (1989). 
pretation. . . . If necessary, the court should similarly determine the policy expressed by the foreign law, and whether the foreign state has an interest in the application of its policy. ${ }^{107}$

This "governmental interests analysis" serves to distinguish "false conflicts" (cases in which only one state has expressed an interest that would be furthered by applying its law) from "true conflicts" (cases in which both states have an interest in applying their law). In the case of false conflicts, Currie recommended applying the law of the state whose interest would be furthered, without resort to jurisdiction-selecting rules or the escape devices that had grown up around them. ${ }^{108}$

Currie's governmental interests analysis requires the court to identify the interested jurisdictions and determine what interests each has in the outcome of the case. "Interest" in this sense is not limited to intervention in the proceedings or any other outward manifestation of a desire for a particular outcome. According to Currie, the jurisdiction's interests should be determined by the "[f]amiliar [process] . . of construction or interpretation." 109 The Second Restatement of Conflicts incorporates Currie's suggestion by listing a number of factors a court should consider in choosing the applicable law, including "the needs of the interstate and international systems," "the relevant policies of the forum," and "the relevant policies of other interested states and the relative interests of those states in the determination of the particular issue."110

${ }^{107}$ Brainerd Currie, Notes on Methods and Objectives in the Conflict of Laws, 1959 Duke L J 171, reprinted in Currie, Selected Essays on the Conflict of Laws 177, 183-84 (cited in note 11 ).

${ }^{108}$ Id at 180-82. If the case involved a true conflict, Currie contended that the solution required balancing the competing interests of each state, a necessarily political endeavor beyond the capacity and the competence of courts. Absent congressional action, Currie recommended that courts apply the law of the forum, since they are constituted as instruments of state government. Professor Kramer has criticized this aspect of Currie's theory as incompatible with the basic premise that conflict of laws cases should be decided according to the same method as other cases. According to Kramer, because a "normal" lawsuit requires the plaintiff to plead and prove an applicable right arising under some law, conflicts cases should be decided similarly. This approach mandates that a court determine, first, whether the defendant can lay claim to a superior right that is also intended to apply to the facts at issue. See Kramer, 56 U Chi L Rev at 1308-09 (cited in note 106); see also Larry Kramer, Rethinking Choice of Law, 90 Colum L Rev 277 (1990).

${ }^{208}$ Currie, Methods and Objectives, in Currie, Selected Essays on the Conflict of Laws at 183-84 (cited in note 11).

${ }^{110}$ Restatement (Second) of Conflict of Laws $\S 6$. The Restatement's list continues with other factors not explicitly related to governmental interests. The court in Edelmann relied on these factors in its choice of law analysis. 861 F2d at 1295. 
C. Accommodation of Relevant Interests

In applying interest analysis to foreign branch deposit cases, courts should consider the interests of at least three jurisdictions in addition to systemic interests reflected in public international law norms. First, the United States (at both the federal and state levels) has an interest in regulating banks that are established and operated under its laws. Second, the foreign state in which the foreign branch operated may have an interest in regulating transactions entered into within its jurisdiction. Finally, the state of which the depositor is a citizen and the state in which she resides (if different) may each have interests in ensuring that the legitimate expectations of their citizens or residents are fulfilled. In addition to these distinctly "governmental" interests, foreign branch deposit cases also present the need to consider the interests of the community of nations as a whole.

1. U.S. state and federal interests.

Interests of the United States in foreign branch deposit cases should be separated into interests of state and federal governments, because each typically has somewhat different concerns. Interests at the state level include ensuring the enforcement of bank deposit agreements as contracts, and ensuring the fulfillment of the legitimate expectations of the state's citizens or residents. Federal interests include conformity with foreign policy and consistency within the national bank regulatory regime. In weighing these interests, the courts should consider whether the safety and soundness of the federal reserve or insurance systems are at issue, and also whether the deposit agreement itself contemplated that U.S. law would be applied in the event of expropriation.

The state's interests in regulating the banking relationship will likely vary among the states. American states generally have an interest in enforcing contracts made by individuals domiciled within their borders or banks chartered under their laws. The depositor enters into a contractual agreement with the bank when she deposits her funds into an account. The bank assumes a debt in the amount of the principal deposit, plus an agreed-upon rate of interest. State contract law normally provides a cause of action for depositors whose demands for their funds have not been satisfied. ${ }^{111}$

${ }^{121}$ See 5B Michie on Banks and Banking $\S 350$ (cited in note 3). 
Federal interests include ensuring a coherent and consistent foreign policy. ${ }^{112}$ Because virtually all large banks with active foreign operations are members of the federal reserve system, the federal government also has a substantial interest in ensuring that consistent, uniform rules apply to all foreign operations of national banks. ${ }^{113}$ Federal banking statutes and regulations have traditionally included specific provisions for foreign branches that treat foreign branches differently from their U.S. parents. ${ }^{114}$ The role of the Federal Reserve as arbiter of monetary policy and as lender of last resort also implicates the U.S. interest in foreign branches as part of a broad national economic interest. In addition, Congress, in exercising its power "to regulate Commerce with foreign Nations," may have a constitutional interest in ensuring the competitiveness of the foreign operations of U.S. banks. ${ }^{115}$

The federal government has argued recently that, to ensure the consistency of domestic banking regulation, "sovereign risks" such as expropriation should be borne by the depositor, while "financial risks" such as poor lending practices or robbery of the branch would be borne by the bank. ${ }^{116}$ Others have challenged this distinction, arguing that in order to preserve American preeminence in international banking, courts should force U.S. banks to honor all obligations entered into by their branches. ${ }^{117}$

Thus, in foreign branch deposit cases, the state's interests in ensuring the enforcement of the contract between the depositor and the bank may be in some tension with the interests of the federal government if the case presents a threat to the adequacy of

${ }^{112}$ See, for example, United States v Curtiss-Wright Export Corp., 294 US 304, 315-18 (1936).

${ }_{113}$ See Brief for United States as Amicus Curiae, Citibank v Wells Fargo Asia Ltd., No 88-1260 (later reported at $110 \mathrm{~S} \mathrm{Ct} 2034$ (1990)), on writ of certiorari 1-3; Brief for United States as Amicus Curiae, Wells Fargo Asia Ltd.v Citibank, No 87-7685 (2d Cir), on remand from Supreme Court 3-5, 27, 33-34.

${ }^{114}$ See 12 USC $\S 321,601,1828(d)(2)$, and 12 CFR Pt 211 (requiring regulatory approval prior to establishment of foreign branches); 12 USC § 604 (requiring U.S. banks to keep separate accounting for foreign branches); 12 USC $\$ 461$ (b)(6) (exempting most foreign deposits from reserve requirements); 12 USC $§ 1813(i)(5)(a)$ (exempting most foreign deposits from FDIC insurance assessments).

${ }^{215}$ US Const, Art I, § 8, cl 3. See also 12 USC § 601 (1988) (giving the Federal Reserve Board regulatory authority to promote "foreign commerce of the United States").

${ }^{116}$ Brief for United States as Amicus Curiae, Wells Fargo Asia Ltd. v Citibank, No 87. 7685 (2d Cir), on remand from Supreme Court 21-28.

${ }^{117}$ See Smerdresman and Lowenfeld, 64 NYU L Rev at 788-94 (cited in note 2). See also Brief of Bank of Montreal, et al as Amici Curiae supporting Wells Fargo Asia Ltd., Wells Fargo Asia Ltd. v Citibank, No 87-7685 (2d Cir), on remand from Supreme Court 1428. 
the federal regulatory regime or has the potential for embarrassing consequences to U.S. foreign policy. In such a situation, a court must weigh the relative importance of both in light of the particular facts of the case. The adoption of a federal choice of law rule in no way precludes the choice of state law as a rule of decision. ${ }^{118}$ Thus, a court faced with a tension between federal and state interests need not necessarily resolve it in favor of federal interests.

\section{Interests of the foreign sovereign.}

An expropriating government may have an interest in securing the assets of the branch within its borders, but may have little or no interest in the outcome of a dispute between a depositor and the bank's home office. If the foreign government has already achieved its purposes by nationalizing the assets held by foreign institutions, it may be indifferent to whether the bank's home office is required to honor its deposit agreements. The court's decision will neither deplete the foreign government's treasury nor lessen the impact of the expropriatory decree. ${ }^{110}$

A suit between a depositor, currently residing in the United States, and the U.S. bank's home office involves two parties who, for the purposes of the dispute, have no contemporaneous connection with the foreign country. The plaintiff's claim in such a case is not that her foreign funds should be repaid by the foreign branch or its successor in interest, the foreign government (if that were so, she would have brought suit in the foreign court), but that the home office itself owes her a debt which it should repay. ${ }^{120}$

Generally, the foreign government's expropriation decree will seek to reach no further than the nation's borders. Certainly the government could not reasonably have expected that American courts would assist in the enforcement of such a decree, given the U.S. public policy against such orders. Consequently, the choice between U.S. and foreign law in many foreign branch deposit cases may present what Currie termed a "false conflict," since the United States has numerous interests in enforcing the deposit agreement and the foreign government has no discernible compet-

${ }^{118}$ See Aaron Ferer, 731 F2d at 120-21 (applying federal common law choice of law approach to conclude that New York substantive law governs).

110 The interest of the foreign government may be more substantial in the case of exchange controls, where an ongoing relationship exists between the government and the branch. See Wells Fargo, 852 F2d 657 .

120 If the depositor is a national of the expropriating government, that government might have a greater interest in enforcing its economic laws and regulations on the individual. 
ing interest. ${ }^{121}$

Because the imposition of liability on the home office may result in the establishment of fewer foreign branches, the foreign government may have an economic interest in preventing home office liability. Such an interest is attenuated, however; the act of expropriation itself provides a strong disincentive to banks considering opening foreign branches in that country, and the additional cost of liability to those depositors who can make their way to U.S. courts represents only a marginal increase in the loss suffered from expropriation.

3. Systemic interests of the international community.

In addition to the particular interests of the United States and foreign governments, the peculiar circumstances of foreign branch deposit cases implicate interests of the world community. To the extent that an expropriation may have violated norms of public international law, such a factor would weigh against choosing foreign law. The perceived effect on the diplomatic and economic relations between the United States and the foreign government might also bear on the choice of law analysis.

As members of the community of nations, sovereign states are governed by the norms of public international law. ${ }^{122}$ A sovereign has an undisputed right to expropriate assets within its territory and to impose restrictions on the export of goods, including foreign currency. ${ }^{123}$ Although some compensation is probably required, the international legal norms governing the compensation due to a state whose nationals' assets have been expropriated remain a subject of significant controversy. Many expropriations have involved no compensation at all. ${ }^{124}$

Although Sabbatino declined to invoke an "illegality exception" to the act of state doctrine, the Court indicated that it declined to apply international legal standards to the Cuban government's expropriations only because there was "disagreement as to [the] relevant international law standards."125 The Court held that:

\footnotetext{
121 There may still be a "true conflict" between U.S. federal and state interests.

122 See Louis Henkin, et al, International Law: Cases and Materials 4-13 (West, 2d ed 1987).

12s In the absence of any treaty or other agreement forbidding expropriation. Id at 1107.

124 See the discussion in Sabbatino of the dispute regarding the validity of expropriation under international law standards. 376 US at 428-32. The Cuban and Vietnamese decrees both involved expropriation without compensation.

125376 US at 430.
} 
the Judicial Branch will not examine the validity of a taking of property within its own territory by a foreign sovereign government, extant and recognized by this country at the time of suit, in the absence of a treaty or other unambiguous agreement regarding controlling legal principles, even if the complaint alleges that the taking violates customary international law. ${ }^{126}$

This construction depreciates the importance of customary international law in favor of "positive" or treaty law, but it does create an exception to the act of state doctrine when the act is alleged to violate a treaty or other multinational agreement. ${ }^{127}$

Although foreign branch deposit cases cannot be decided solely by reference to public international law, the needs of the international system should be acknowledged in the interest calculus. Abandoning the current territorial approach to foreign branch deposit cases would permit an explicit consideration of whether the U.S. court would give effect to a taking of property accomplished in violation of international legal norms. This Comment's suggestion that the act of state doctrine may not be implicated in these cases leads to the conclusion that this area of the law is ripe for development of international legal standards by domestic courts. ${ }^{128}$ Many scholars already contend that the act of state doctrine should be construed narrowly to allow U.S. courts to contribute to the development of customary international law. ${ }^{129}$

126 Id at 428 (emphasis added).

${ }^{127}$ For a discussion of the treaty exception, see Richard A. Falk, The Role of Domestic Courts in the International Legal Order 72-112 (Syracuse, 1964) (arguing that U.S. courts should not interfere in the domestic affairs of foreign nations); J. Anthony Kline, An Examination of the Competence of National Courts to Prescribe and Apply International Law: The Sabbatino Case Revisited, 1 USF L Rev 49, 81-93 (1966) (criticizing Falk's thesis). For a review of the treaty exception's reception in the courts, see Bazyler, $134 \mathrm{U} \mathrm{Pa} \mathrm{L} \mathrm{Rev} \mathrm{at}$ 371-72 (cited in note 76). For an example of the treaty exception, see Kalamazoo Spice Extraction Co. v Provisional Military Government of Socialist Ethiopia, 729 F2d 422, 42728 (6th Cir 1984).

${ }^{128}$ See Falk, The Role of Domestic Courts at 112-14 (cited in note 127).

129 See, for example, Jay L. Westbrook, Extraterritoriality, Confict of Laws, and the Regulation of Transnational Business, 25 Tex Intl L J 71, 74-75 (1990) (act of state and choice of law are but two aspects of the larger problem of regulation of transnational conduct); Wood, Government Involvement at 31 (cited in note 36) (act of state should be narrowly construed when a violation of international law is alleged in order to allow domestic court decisions to contribute to the body of international law). 
D. Interest Analysis in Operation

The facts of the Vietnamese cases provide an illustration of how interest analysis would operate in foreign branch deposit cases. The foreign interest in such a case, brought by a U.S. resident against a U.S. bank's home office, is very small. The relationship between the banks and the Vietnamese government had effectively ended before the expropriation decree was issued. Once the banks closed their branches and evacuated their personnel, the foreign government's interests in the outcome of litigation in the United States became negligible.

Systemic interests in such a case are also relatively small. Although the fact that the government was established by armed conflict could be a violation of international law, it might also be defended on the basis of self-determination. Importantly, the United States did not and has not recognized the new government of Vietnam. ${ }^{130} \mathrm{~A}$ failure to give effect to the Vietnamese expropriation decree would not embarrass the U.S. in its foreign relations, because U.S. foreign policy toward Vietnam is premised on the idea. that the Vietnamese government has no sovereign authority. ${ }^{131}$

The act of state doctrine would not apply to such a case for at least two reasons. First, under Kirkpatrick, the attempt to recover a debt from the bank's home office would not challenge the validity of the Vietnamese decree. Second, under the recognition requirement enunciated in Sabbatino and Sokoloff, the actions of an unrecognized government are not afforded the presumption of validity under the act of state doctrine; nor would they potentially embarrass the executive branch's conduct of foreign relations.

A U.S. state has obvious interests in enforcing contracts between banks and depositors in wholly domestic situations; the involvement of a foreign branch should not diminish this interest. Admittedly, if the plaintiff moves to the state after the expropriation, as in Trinh and Vishipco, this interest is less immediate. Moreover, as argued above, no important U.S. foreign policy interests are implicated here. Whether the federal interests in the safety and soundness of the banking regulatory regime are genu-

130 See Restatement (Third) of the Foreign Relations Law of the United States $\$ 202$, Reporters' Note 6; Republic of Vietnam v Pfizer, 556 F2d 892 (8th Cir 1977). Recognition is important in international relations and is determined by individual nations. See Restatement (Third) of the Foreign Relations Law of the United States §§ 202-05.

131 This analysis follows the Sabbatino Court's emphasis on recognition at the time of suit as a requirement for invocation of the act of state doctrine. See 376 US at 428 . 
inely threatened by such suits presents a difficult question that courts have not addressed in previous cases. ${ }^{132}$ Although such an interest would seem quite strong if actually implicated by suits like these, a court would still have to determine whether it preempts state contract law. ${ }^{133}$ Without additional information, it is impossible to determine how suits such as Trinh and Vishipco would affect the federal regulatory scheme. At first blush, however, the state interest in enforcing contracts weighs quite heavily and should be overcome only by evidence of real risk to safety and soundness.

Thus, interest analysis would probably lead to the application of state contract law to decide the dispute in cases like Trinh and Vishipco. Of course, courts engaged in the balancing required by interest analysis could reach different outcomes. The method demonstrated here nonetheless has the distinct advantages of being more methodologically direct and consistent than the approaches used by courts in recent foreign branch deposit cases.

\section{Conclusion}

The current law governing suits to recover foreign branch deposits suffers from two main problems. First, the courts use the illsuited doctrines of ultimate liability, separate entity, and act of state to solve a conflict of laws problem. Second, the choice of law results of those doctrines exhibit all the defects of the now-discredited territorial approach to conflict of laws analysis. International banking law should recognize the futility of using debt situs analysis to localize transactions with multinational contacts.

An explicit investigation into the governmental interests implicated in the actual case would permit courts to make reasoned decisions regarding the law governing these types of transactions. It would also foster rules of decision specifically tailored to the problems of foreign branch deposits. The development of rational conflicts rules to be applied in foreign branch deposit cases would increase predictability (at least as to the method for determining the applicable law), and enhance depositors' and bankers' investment decisions. The current practice of resorting to escape devices

${ }^{132}$ This will be an issue in the Second Circuit's consideration of the Wells Fargo case on remand. See sources cited in notes 113, 117.

${ }^{133}$ See Brief of Bank of Montreal, et al as Amici Curiae supporting Wells Fargo Asia Ltd., Wells Fargo Asia Ltd. v Citibank, No 87-7685 (2d Cir), on remand from Supreme Court 14-18. 
to avoid the implications of imported doctrines can only hinder the flow of funds otherwise encouraged by foreign branch banking. 